\title{
The Connection of the Isle of Man with Ireland
}

\section{Author(s): A. W. Moore}

Source: The Celtic Review, Vol. 6, No. 22 (Oct., 1909), pp. 110-122

Stable URL: http://www.jstor.org/stable/30070208

Accessed: 07-06-2016 05:43 UTC

Your use of the JSTOR archive indicates your acceptance of the Terms \& Conditions of Use, available at

http://about.jstor.org/terms

JSTOR is a not-for-profit service that helps scholars, researchers, and students discover, use, and build upon a wide range of content in a trusted digital archive. We use information technology and tools to increase productivity and facilitate new forms of scholarship. For more information about JSTOR, please contact support@jstor.org. 


\section{THE CONNECTION OF THE ISLE OF MAN}

\section{WITH IRELAND}

\section{A. W. Moore}

THE Isle of Man has a share in the earliest legends which take the place of history in Ireland before the Christian era, and perhaps for some little time after it. Cuchulainn and Finn, the most celebrated heroes of Irish story, appear in Manx as well as in Irish tales. It was in the Isle of Man that Culann, the famous smith, manufactured a sword, a spear, and a shield for Conchobar MacNessa, which were of such excellence that he was invited to take up his abode in Ireland. The triumph of Lug, the Irish sun-god, was celebrated in the Isle of Man, as in Ireland, early in August, and the Beltain (May) and Samhain (November) festivals were accompanied by similar observances in both countries. Keating, ${ }^{1}$ an Irish historian, in relating the adventures of the early colonists of Ireland, tells us that the mythic Firbolg and their allies, after their defeat by the Tuatha De Danann, went to the island of Rathlin, and the western isles of Scotland, while, according to "Nennius, ${ }^{2}$ they also took possession of Man. The conquerors of the Firbolg, the equally mythic Tuatha De Danann, are brought closely into connection with the Isle of Man through the great Irish magician, Manannan MacLir, who is said to have been one of their chieftains, and who, according to the 'Supposed True Chronicle of the Isle of Man,' was ' the first man that had Mann, or ever was ruler of Mann, and the land was named after him.' ${ }^{3}$ Cormac, in his glossary, gives the following account of him :

1 Keating, History of Ireland, pp. 106-108.

2 History of Britain, cap. ii.

3 Manx Society Publications, vol. xii. p. 5. A copy of this, which was certainly not compiled earlier than the sixteenth century, was prefixed to old copies of the Statute Book. 
'Manannan MacLir, a celebrated magician who was in the Isle of Man. He was the best pilot that was in the west of Europe. He used to know by studying the heavens the period which would be the fine weather and the bad weather, and when each of these two times would change. Inde Scoti et Brittones eum deum vocaverunt maris, et inde filium maris esse dixerunt, i.e. MacLir, son of sea. Et de nomine Manannan the Isle of Man dictus est.' I This theory of the Isle of Man being named after Manannan, when so called, has been shown to be highly improbable by Professor Rhys, who thinks that 'Manannan gave his original name, in a form corresponding to Manu and its congeners, to the island, making it Manavia Insula . . . for which we have in Welsh and Irish respectively Manaw and Manann. Then from these names of the island the god derives his in its attested forms of Manawydan and Manannan, which would seem to mark an epoch when he had become famous in connection with the Isle of Man.' This connection began after the defeat of Manannan and his Tuatha De Danann by the Milesians, when he was chosen by the survivors as their leader. $\mathrm{He}$ and they then took refuge in the western isles and Man, whose inhabitants acknowledged him as their ruler. ${ }^{3}$ Referring again to the 'Supposed True Chronicle of Man,' we find that 'he reigned many years and was a Paynim, and kept by necromancy the Land of Man under mists, and if he dreaded any enemies, he would make of one man to seem an hundred by his art magick, and he never had any farm of the Comons, but each one to bring a certain quantity of green rushes on midsummer eve.' Manannan and his dynasty, according to a story called 'The Exile of the Children of Uisneach,' ruled in Man at the beginning of our present era, as the

1 Cormac's Glossary, the Stokes O'Donovan edition, p. 114.

2 Rhys, Bibbert Lectures, 1886, pp. 663, 664.

3 O'Curry, Atlantis, vol. vii. 226.

4 Manx Society Publications, vol. xii. p. 6. This last sentence would seem to have been added as a gentle reminder to the Derby rulers of Man that their faithful subjects had not been accustomed to taxation. 
fourth of that name is stated to have assisted Gaiar in driving Conchobar, king of Ulster, from his dominions early in the first century. Tighernach, who wrote his annals about the end of the tenth century, records that a colony of Cruithnigh, who were driven out of Ulster by the Milesians, took refuge in the Isle of Man in A.D. 254. It is, however, impossible to be sure whether this statement of Tighernach's is authentic history, or is founded on the mythical story of the expulsion of Manannan by the Milesians related above. The two races, however, mentioned by him are certainly human beings, not gods and demons like the Tuatha De Dannan and Firbolg of the earlier legends. Who the Milesians were we know not, but they were probably Goidels, and the Cruithnigh or Picts are historical. It must, therefore, remain uncertain who were the earliest inhabitants of the island, but we have the authority of Orosius, ${ }^{1}$ who wrote in 416 A.D., for the statement that in his time the inhabitants of both Ireland and the Isle of Man were Scoti, or the people who in the Celtic languages would be called Gael and Gwyddyl. It would seem probable, however, judging from the populations of the adjacent countries at this period, that, though Goidels were the ruling people, other earlier races were represented. Till the fifth century, then, we have no historical fact recorded in connection with the Isle of Man, except that it had a population similar to that which inhabited Ireland. Nor are we better supplied with historical records during the fifth and three following centuries, though fortunately we are able, to a certain extent, to supply their place through the survival of the names of Irish ecclesiastics in the designations of our parish churches, which are usually on old sites, and of the ancient keeills or cells. These names would lead us to suppose that Manxmen were for the most part Christianised by Irish missionaries; and, indeed, it would have been strange if the proselytising Irish monks, who wandered all over Europe,

1 Manx Society Publications, Lib. I. 
had avoided an island so near to them. Whether St. Patrick visited the Isle of Man or not is not certainly known, as the ancient records are silent on this point. The Tripartite Life of $\delta$ t. Patrick ${ }^{1}$ contains the following interesting account of the conversion of Manxmen to Christianity: 'St. Patrick having by means of a miracle converted a wicked man of Ulster called Macc Cuill and his men, the following incident is related. "Then they were silent and said, 'Truly this man Patrick is a man of God.' They all forthwith believed, and Macc Cuill believed, and at Patrick's behest he went in the sea in a coracle of [only] one hide. . . . Now Macc Cuill went on that day to sea, with his right hand toward Mag Inis, till he reached Mann, and found two wonderful men in the island before him. And it is they that preached God's word in Mann, and through their preaching the men of that island were baptized. Conindri and Romuil were their names. Now when these men saw Macc Cuill in his coracle they took him from the sea and received him with a welcome; and he learnt the divine rule with them, until he took the bishopric after them." This is "Macc Cuill from the sea," the illustrious bishop and prelate of Arduimnen.' 2

With regard to the earliest bishops of the Isle of Man, the monks of Rushen Abbey-and monks are usually credulous in such matters-wrote: 'We are entirely ignorant who or what were the bishops before Roolwer's time (1076); for we neither find any documents on the subject, nor have we any certain accounts handed down by our elders.' ${ }^{3}$ Undaunted by this, the later Manx historians have compiled $a$ list of them as follows : 'Amphibalus (doubtful), 360 ; St. Patrick, 444 ; St. German, 447 ; Conindricus, Romulus, etc.' The two latter are clearly the same as those mentioned in the Tripartite Life. Colgan gives these names as Conderium et Romailum,

1 Stokes's translation, p. 223.

2 Colgan, according to Stokes, has Ard-Ebnanensis.

3 Chronicon Mania, Manx Society, vol. xxii. p. 115

VOL. VI. 
which, Professor Rhys conjectures, should become in Manx something like Conner or Coinnir and Rowell or Rowill. With reference to the former of these two names, it is, perhaps, significant that, according to the Annals of Ulster, the shrine of DaChonna, probably in Man, was, in 798, plundered by the Norsemen. Now $d a$, like mo, is a prefix expressing endearment, and removing it we have Conna, so that this shrine may have been that of the holy man mentioned in the Tripartite Life. As to Rowell, it is just possible that he may have left his mark in the name of the mountains called Barroole, the creek called Ghaw Roole, and the hill called Knockrule. To Mace Cuill we refer later. His name in the form Coole is common in the Isle of Man at the present day. With regard to St. Patrick, then, the evidence from the Tripartite Life would tend to show that he had not visited the Isle of Man. It was reserved for Jocelin, a monk of Furness, writing early in the twelfth century, who may, however, have had access to information not attainable now, to tell us that he did so ; and his narrative is expanded and embellished by the Supposed True Chronicle of Man and the Traditionary Ballad, both probably of not earlier date than the sixteenth century. Whether St. Patrick did or did not come to the island, we have made use of his name freely in!our sacred sites. Of our seventeen parish churches and the thirty ancient keeils, which have retained their names, the great majority are dedicated to him, and to saints who are known to have been either his disciples or their successors. The names of nine of the parish churches are almost certainly of purely Irish origin, and, of the remaining eight, four are probably Irish, and four of comparatively recent dedication. St. Patrick's own name was given to two, Kirk Patrick, and Kirk Patrick of Jurby. Jurby point, on which the latter church is situated, is said to have once been an island, the innis Patrick, ${ }^{1}$ where the saint is supposed to have landed. There is also a church on Peel

1 Some think, and with more probability, that innis Patrick is Peel Isiand. 
Island dedicated to him, which is of very early date. Maughold, assuming him to have been identical with the Macc Cuill already mentioned (p. 113), ${ }^{1}$ is said to have been one of St. Patrick's earliest disciples, has given his name to a parish, a headland and an islet. The Book of Armagh records the marvellous story of his conversion by St. Patrick, and in the other accounts of St. Patrick's life are equally wonderful details about his episcopate. These are all perhaps surpassed by the circumstantial statements in the Chronicon Mannice concerning his reappearance in the twelfth century to strike dead with his staff a daring pirate who had profaned his sanctuary.

It has been suggested that Lonan, St. Patrick's nephew, has given his name to the parish church of Lonan, or, as it is now usually spelled, Lonnan, but it is more probable that this name has been derived from that of Adamnan, the illustrious abbot of Iona, and the writer of the Life of St. Columba. This name is pronounced awnan, or onan, in Ireland, and Keeill Adamnan or onan, 'Adamnan's Cell,' easily becomes Lonan. From Connaghyn, as he is called in the 'Traditionary Ballad,' comes the name of the parish church of Conaghan, as it was called in the earliest record, but since contracted into Conchan. It is difficult to connect him with any Irish saint mentioned in the martyrologies, but he is probably identical with St. Connigen, whose name occurs in the calendar of Engus. The popular idea that Conchan is named after St. Concha (Latin Concessa), St. Patrick's mother, cannot be accepted philologically. The parish church of Marown is dedicated to a saint called Maronog ${ }^{2}$ in the Irish calendars, Marooney in the 'Traditionary Ballad,' and St. Runi $^{3}$ in the manorial roll of 1511. In a Bull of Pope Gregory IX., dated 1231, the church of this parish is called

1 The phonetic change involved is improbable though not impossible. See Manx Names, A. W. Moore, p. 136. Elliot Stock, London, 1903.

2 The prefix mo, 'my,' and the affix og, 'young,' are expressive of endearment and are frequently attached to the names of Celtic saints.

$\therefore$ Genitive.

+ See English Historical Review, January 1890. 
kyrke Marona. In the parish now called Arbory there are two keeils dedicated to Cairbre and Columb respectively, the former being an Irish saint and the latter the famous Irish missionary to the Scots, St. Columba. The parish formerly took its name from both of these saints, being sometimes called after one and sometimes after the other. In 1153 it is the parish of $S^{t i}$ Columbo, herbery vocatam. In 1291 it was Carber's, and in 1511 Columba's parish, but the name of the former has proved more enduring than that of his more illustrious compeer. The church of the parish of Santan or Santon, called in 1511 St. Santan, is named after St. Sanctan, also an Irish saint, not from St. Ann, as the modern map-makers have it. The parish church of Bride, called in $1511 \mathrm{St}$. Brigide, is dedicated to St. Brigit, the most famous of Irish female saints.

We now come to the names of those parish churches and parishes which are of doubtful, but still probably Irish, origin. With regard to the first of these, that of German, which has been given to the cathedral of the diocese as well as to a parish church and its parish, the 'Traditionary Ballad' tells us that St. Patrick, before he left the Island, 'blessed Saint Germanus, and left him a bishop in it to strengthen the faith more and more.' ${ }^{\prime}$ A difficulty, however, arises from the fact that the name of Germanus does not occur in the Irish calendars, and we have only the comparatively recent authority of Jocelyn for his being St. Patrick's disciple. By way of solving this it may not, perhaps, be unreasonable to conjecture ${ }^{2}$ that Germanus was substituted for Coemanus by later writers, who would remember the famous saint of Auxerre, while forgetting the obscure Irishman. This Coemanus, or, as he is called in Irish martyrologies, Mochæmog, is known to have been one of St. Patrick's disciples. The name of the parish church of Braddan has been connected with the famous

1 Train, History of the Isle of Man, p. 52.

2 This is not an original conjecture of the writer's. He has seen it somewhere, but cannot remember where. 
Irish saint and navigator, Brandinus or Brendinus, or with the St. Brandon who, though not mentioned by the monks of Rushen Abbey, was, according to Manx historians, bishop of Sodor and Man from 1098 to 1113. This theory does not seem consonant with orthodox philology, but nevertheless it may be correct. In 1231 the Bull of Pope Gregory IX mentions terras $S^{t i}$ Bradarni, and in 1291 Bishop Mark held a synod at Bradan.

The name of the parish of Rushen, which is first mentioned in 1408 as of Sanctoe Trinitatis inter prata, 'of the Holy Trinity among the Meadows,' presents considerable difficulties. In the first manorial roll of 1511 it is called Parochia $S^{t i}$ Trinitatis in Rushen. The most probable interpretation seems to be that Rushen has derived its name from St. Russein of Inis-Picht, whose name is recorded in the martyrology of Tallaght, and who was probably forgotten before 1511, when, Rushen being regarded as a place-name, in may have been substituted for noo, saint. The parish church of Malew is generally supposed to have derived its name from St. Lupus, the pupil of St. German of Auxerre, who was sent to Britain to confound the Pelagians. In confirmation of this theory may be quoted the inscription on an ancient paten, now in Malew church, Sancte Lupe, ora pro nobis, and the entry in the roll of 1511, Parochia $S^{t i}$ Lupi. It is more probable, however, that the name may come from that of an Irish saint, Moliba or Molipa, the Latinised form of Moliu or Malliu, whose name is found in the Calendar of CEngus, and in the form Moliwe in a Bull of Pope Gregory XI., relating to a presentation to this very church, dated 1377. The four remaining parishes, Andreas, Michael, Ballaugh, and Lezayre, had probably no churches till after the connection with Ireland had come to an end; the two latter parishes, indeed, having been mainly occupied by marshes till a comparatively recent date.

Of the ancient keeills referred to above, the remains of more than one hundred are still to be found, the earliest 
of which probably date from the sixth century, and of their names about thirty survive. They are for the most part of very small size, not exceeding twenty feet by twelve. This fact, and their remarkably irregular distribution, conclusively disprove the theory advanced by the 'Traditionary Ballad' that they were the chapels established by St. German for public worship, one for each four quarterlands. ${ }^{1}$ Their only possible use, therefore, was as habitations for the Culdees or clerical recluses. St. Patrick and St. Bridget have each given their names to seven of these keeills. St. Martin, possibly the St. Martin who is said to have been St. Patrick's uncle, has one keeill called after him. St. Columba has one, and Lingan, also an Irish saint, two.

But it is not only through these names that we are able to trace the intimate connection of the Isle of Man with Ireland between the fifth and eighth centuries, for we find that the round tower on Peel Island is precisely of the same form as that in Ireland, and that the inscriptions in the Ogam character recently discovered are, according to Professor Rhys, of the oldest Irish type. A very significant story, as showing this connection, is related by Cormac in his glossary concerning the visit of Senchan Torpeist, who was chief poet of Ireland from A.D. 649-62, to the Isle of Man. It appears that he took with him fifty poets as his retinue, besides students, and that on their arrival in the island the first person they saw was an old woman on the shore cutting seaweed, who asked them who they were. On their replying, she gave them a couplet of verse and challenged them to give the corresponding couplet, which one of their number did. This anecdote would tend to show that the Isle of Man was one of the regular circuits of the Irish poets, and that its language was at that time identical with the Irish. These visits of Irishmen to the Isle of Man were doubtless returned by visits of Manxmen to Ireland. For it must be remembered that till the end of the eighth century Ireland was the centre of European

1 Each quarterland contains on an average seventy-five acres. 
culture and civilisation as well as of religious zeal, and the Irish Church was so celebrated as a school of learning that students flocked to Ireland from great distances. Till the inroads of the Northmen, there seems to have been only one ${ }^{1}$ break in this period of peace and prosperity, which took place at the beginning of the seventh century, when it is recorded by Bede that the Mevanian Islands ${ }^{2}$ were conquered by Edwin of Northumbria. It is, however, doubtful if Man is included under this term, for King Alfred, in his translation of Bede's text, substitutes Anglesey for Mevanias Insulas, and William of Malmesbury, writing in the twelfth century, quotes Bede's words, and remarks that 'the Mevanian Islands are those which we now call Anglesey, that is, the Isles of the Angles.' ${ }^{3}$ It is, however, curious that the plural should be used. Even if the Isle of Man had been conquered by Edwin, there would not have been any permanent results, as the English were driven from the coasts of Cumberland and Lancashire soon afterwards, and consequently it is not likely that they retained their hold on the small island to the west of those coasts. The probability seems to be that the Isle of Man remained under Ultonian rule, and, therefore, in close connection with Ireland, till the incursions of the Northmen, and that even then this connection did not entirely cease, for, if the account in the Book of Rights is credible, the Isle of Man was tributary till the tenth century, and the King of Ireland enjoyed ' the fruit of Manann in Tara.' +

1 The exploits attributed to Baetan MacCairill, King of Ulster, at the end of the sixth century, were, till the publication of Celtic Britain, by Professor Rhys, supposed to have taken place in the Isle of Man ; but he has shown that they really occurred in the region called in Welsh the land of Manaw, and by the Goidels Mannan, which is the country between the Firths of Clyde and Forth.

2 Mevanias Brittonum insulas, qua inter Hiberniam et Brittaniam sito sunt.Ecclesiastical History, lib. II.

3 It is perhaps worth noting that Train (History of the Isle of Man, pp. 37-49), misled by the identity of the early name of Anglesey-Mona-with that of the Isle of Man, has introduced a dynasty of Welsh kings, whom he made to rule in Man from A.D. 517-919, whereas the Welsh isle was really the sphere of their dominion.

4 O'Donovan, Book of Rights, 1847, pp. 3, 9. 
Apart, however, from the fact that all references to Manann do not necessarily apply to the Isle of Man, it seems improbable that the tribute was regularly paid, as the incursions of the Northmen, which began at the end of the eighth century, continued at short intervals, till they definitely established their rule. The first of these incursions is recorded by the Annals of Ulster in 798 in the following words : 'The burning of InisPatrick by the Gentiles, and cattle plunder of the country was borne off, and the shrine of Dachonna was broken by them, and the spoils of the sea (taken) by them also, between Erinn and Alba.' O'Donovan understood the Inis-Patrick here mentioned to be the island so called on the coast of Dublin, while Todd, in his introduction to the Wars of the Gaedhill with the Gaill, considered it to refer to Peel Island in the Isle of Man.

The mention of the shrine of Dachonna would tend to show the correctness of the latter opinion, and, even if it were not so, it is not likely that the pirates who took 'spoils of the sea between Erinn and Alba' (Scotland) would have avoided the Isle of Man. Such expeditions were evidently merely for plunder, as there was at that time no attempt to establish any form of government. This latter process probably began about the middle of the ninth century, when a Scandinavian dynasty, whose power extended along the greater portion of the east coast of Ireland, was seated at Dublin. This change of rulers, even if it did not extend to Man, would put an entire stop to any direct intercourse with the Irish Court, and to the payment of the tribute at an earlier date than that mentioned by the Book of Rights. It is clear, too, from the frequent mention of the gall-gaedhel by the Irish annalists as being the inhabitants of Man and the Isles, that a considerable number of Scandinavian colonists must have at this time effected a permanent settlement in these islands ; for the gall-gaedhel are described as being a mixed race, partly Gaelic and partly Norse. It was not till 1060 
that, according to the Four Masters, Murchadh, son of Diarmaid, King of Dublin and Munster, having driven out the Danes in 1052, 'went to Manann, and carried tribute from thence.' This was apparently only a temporary success, as in 1072 the Danes were in possession of Dublin, and in 1079 the Isle of Man was conquered by the Scandinavian Godred Crovan, who afterwards subdued Dublin and a great part of Leinster. Godred's son Lagman succeeded, presumably, to the same dominion, but on his death in 1096, Celtic rule again revived for a brief space; for we find that the 'chiefs of the Isles' (Sodor and Man) recognised the King of Ireland as their overlord by sending messengers to ask him to appoint 'some competent person of the royal race to be their king, till Olave, son of Godred, should have grown up.' ${ }^{1}$ Murchadh consequently nominated Donald, a kinsman of his own, who soon began to govern so tyrannically that after three years' reign he was summarily expelled by the Manx. Then, in 1113, after the two expeditions of Magnus, King of Norway, Scandinavian rule was firmly re-established in Man and the Isles under Godred Crovan's son Olave, and Olave's son Godred, powerful rulers, who entered into alliances with the Irish kings on equal terms. Under their successor Reginald, who ascended the throne in 1188, English influence began to make itself felt both in Ireland and in the Isle of Man. In the Isle of Man it increased so much that in 1213 Reginald did homage to John, who in 1214 took him, ' together with his possessions . . . under our protection.' ${ }^{2}$

Thus ended the political connection of Man and Ireland. In other respects, however, the connection between the two countries continued. Towards the end of the fourteenth century, probably on account of the Statute of Kilkenny, a number of Irish, bearing, for the most part, Hiberno-Norman names, such as MacWalter, MacWilliam, and MacGibbon, came to Man, where they flourished and

1 Chronicle of Man, vol. xxii., Manx Society's Publications.

2 Manx Society's Publications, vol. vii. pp. 36, 37. 
increased in numbers. In one way only was their fate possibly a worse one than if they had remained in Ireland, and that was in regard to their names, as the euphonious designations referred to gradually became corrupted into Qualtrough, Quilliam, and Cubbon.

Another bond between Man and Ireland was trade. Till 1765, when Man came under the direct influence of the English commercial system, its trade with Ireland, mainly by way of Dublin and Peel, was greater than with any other country.

Altogether, as you will have seen, the connection between the two countries has been a very intimate one. The chief token of this at the present day is the nomenclature, both of places and of persons, in the smaller island. Between sixty and seventy per cent. of the Manx place-names and personal names are of Goidelic origin, about twenty per cent. being Scandinavian, and the rest English. But the most significant fact, as showing the connection, is that the forms taken by the Goidelic names, especially by the personal names, which are, generally speaking, older than the place-names, are those which are more usual in Ireland than in Scotland, though the language, owing to the more recent connection with Scotland (the Isle of Man having been under Scottish rule during the latter part of the thirteenth century), approaches somewhat more closely to Scottish than Irish.

Though Man now looks eastwards, rather than westwards, it has a remaining bond which still links it closely to Ireland, a bond that never can be broken-the bond of race. This shows itself in the strong sympathy between Irishmen and Manxmen. They assimilate easily, and they ' get on' well together. Let us hope, in conclusion, that the old Manx proverb, 'Mie Nherin, mie Mannin,' i.e. 'What is good for Ireland is good for Man,' may prove to be an apt one politically as well as in other respects. 